Original Research Paper

\title{
Phenotypic Characterisation of South African Unimproved Indigenous and Tankwa Goats
}

\author{
${ }^{1,2}$ Fhulufhelo Vincent Ramukhithi, ${ }^{3}$ Khoboso Christina Lehloenya, ${ }^{4,7}$ Antoinette Kotze, \\ ${ }^{2}$ Khathutshelo Agree Nephawe, ${ }^{5}$ Tlou Caswell Chokoe, ${ }^{6}$ Mokagadi Magdelin Seshoka, \\ ${ }^{6}$ Thinus Jonker and ${ }^{1,2}$ Tshimangadzo Lucky Nedambale \\ ${ }^{I}$ Germplasm, Conservation and Reproductive Biotechnologies, Agricultural Research Council, Pretoria, South Africa \\ ${ }^{2}$ Department of Animal Sciences, Tshwane University of Technology, Pretoria, South Africa \\ ${ }^{3}$ Department of Agriculture, University of Zululand, Durban, South Africa \\ ${ }^{4}$ Research and Scientific Services, National Zoological Garden, South African National Biodiversity Institute, Pretoria, South \\ Africa \\ ${ }^{5}$ Directorate Genetic Resources, Department of Agriculture, Forestry and Fisheries, Pretoria, South Africa \\ ${ }^{6}$ Vaalharts Research Station, Northern Cape Department of Agriculture, Land Reform and Rural Development, Kimberly, \\ South Africa \\ ${ }^{7}$ Department of Genetics, University of the Free State, Bloemfontein, South Africa
}

Article history

Received: 09-06-2019

Revised: 18-09-2019

Accepted: 23-10-2019

Corresponding Author: Fhulufhelo Vincent Ramukhithi Germplasm, Conservation and Reproductive Biotechnologies, Agricultural Research Council, Pretoria, South Africa E-mail: ramukhithif@arc.agric.za
Abstract: The aim of this study was to characterise and compare phenotypic characteristics of South African unimproved indigenous and Tankwa goats. Phenotypic characteristics of 44 South African unimproved indigenous and 41 Tankwa goats were assessed. The qualitative characteristics were assessed through visual appraisal. Quantitative characteristics such as body measurements were obtained using a flexible tape, while body weight was determined by using a weighing scale and body temperature with a thermometer. Body condition score of South African unimproved indigenous goats $(98 \%)$ was more satisfactory when compared to that of Tankwa goats (74\%). None of the Tankwa goats had ticks under their tails while 53\% of South African unimproved indigenous goats had them. Most of the Tankwa goats had single or two colours as their main colours. Both goats' types had high proportion of moderate necks, brown eyes, average eye width and mouth shape. Tankwa goats' horns and hooves were more damaged when compared to those of South African unimproved indigenous goats. Tankwa goats had higher phenotypic characteristics (quantitative) with the exception of body temperature. In conclusion, qualitative characteristics were comparable between South African unimproved indigenous and Tankwa goats. However, quantitative characteristics of Tankwa goats were higher, with the exception of body temperature.

Keywords: Body Description, South African Indigenous Goats

\section{Introduction}

South African indigenous goats such as Nguni, Kalahari Red, Savannah and Tankwa (Ramsay and Donkin, 2000; Kotze et al., 2014) are tolerant to different parasites and diseases and are able to survive harsh environments (Pieters, 2007; Kotze et al., 2014). However, some are poorly managed, with limited information on their performance and are under threat of extinction (Webb et al., 1998; Kotze et al., 2014). Extinction of these valuable assets is due to a combination of genes (Visser et al., 2004; Mara et al., 2013), which is caused by increased uncontrolled breeding and the introduction of exotic breeds (Nsoso et al., 2004; Esquivelzeta et al., 2011). According to Roosen et al. (2005); Food and Agriculture Organization $(2007 ; 2013)$, it has been estimated that 22 to $28 \%$ of farm animal breeds became eroded or threatened in the past century and this figure is now expected to be escalating. Therefore, conservation of these goat breeds is important to protect their diversity (Vallecillo et al., 2004; Manzi et al., 2011), because once it is lost it cannot be replaced (Manzi et al., 2011). Moreover, conservation of genetic diversity provides protection against diseases, feed shortages, selection errors, unforeseen disastrous actions, social and climatic 
changes. The main aim of conservation is to keep different genes as pure as possible and to keep special genes of value (Esquivelzeta et al., 2011; Mara et al., 2013).

Phenotypic characterisation is a practice of documenting the physical appearance or characteristics of an animal. The information provided by phenotypic characterisation studies is crucial for planning management and the use of animal genetic resources at local, national, regional and global levels (Food and Agriculture Organization, 2011; Hassen et al., 2012; African Union Interafrican Bureau for Animal Resources, 2014). The phenotypic characterisation tool gathers information on production environment, qualitative, quantitative and adaptive traits (African Union Interafrican Bureau for Animal Resources, 2014). For the conservation and improvement of indigenous animals, phenotypic characterisation should be a first step to be undertaken before the use of their genetic material (Kunene et al., 2007; Yakubu et al., 2010; Hassen et al., 2012).

There are two types of phenotypic characterisation, namely: quantitative and qualitative, which provides information on the identification of unique characteristics within different populations (Yami and Merkel, 2008). Phenotypic qualitative characteristics include the external physical form, shape, colour and appearance of the animals. For examples: coat colour, horn shape and ear length etc (Yami and Merkel, 2008; Hassen et al., 2012; Akpa et al., 2013; Phillips, 2013). These characteristics have less direct significance to the production and service functions of an animal (Food and Agriculture Organization, 2011; Hassen et al., 2012). Phenotypic quantitative characteristics are measures of animal body parts (Pieters et al., 2009; Food and Agriculture Organization, 2011) e.g. body weight and size (Agga et al., 2011; Hassen et al., 2012). These characteristics are more directly associated to production characteristics. For example; body weight and chest girth are directly associated to body size and production characteristics (Agga et al., 2011; Hassen et al., 2012). Phenotypic characteristics have important socio-cultural and economic values to African people. As a result, most farmers have specific respect and choices for specific traits eg goat coat colours and body sizes are more favourable to the farmers (Hassen et al., 2012).

Indigenous goats were regarded as less important animal genetic resource (Pieters et al., 2009; Sahlu et al., 2009). As a result, this has led to their underutilisation and contribution to agriculture (Mekasha, 2007; Manzi et al., 2011). Therefore, an accurate collection of phenotypic information from different South African indigenous goats will assist with future breeding plans, maintenance of unique phenotypic characteristics (Manzi et al., 2011) and will enable an accurate comparison of these goats with other goat breeds (Kunene et al., 2007). The objective of the current study was to characterise and compare South African unimproved indigenous and Tankwa goats' phenotypic characteristics.

\section{Materials and Methods}

The study was approved by ethic committees of the Tshwane University of Technology (REC2012/10/019-2) and Agricultural Research Council (APIEC15/044). The study was conducted at the Agricultural Research Council and Carnarvon Research Station. The Agricultural Research Council is situated on the Highveld (Irene) at an altitude of about $1500 \mathrm{~m}$ above sea level. The temperature ranges from 6 to $21^{\circ} \mathrm{C}$ in winter and 16 to $27.3^{\circ} \mathrm{C}$ in summer. The rainfall ranges from 0 to $1.4 \mathrm{~mm}$ in winter and 84.4 to $106.6 \mathrm{~mm}$ in summer (J Matsapola, 5 May 2015).

Carnarvon Research Station is situated in the Karoo area at an altitude of about $1309 \mathrm{~m}$ above sea level. The temperature ranges from 1.3 to $20^{\circ} \mathrm{C}$ in winter and 17.4 to $36^{\circ} \mathrm{C}$ in summer. The rainfall ranges from 1.9 to $8 \mathrm{~mm}$ in winter and 19.2 to $37.8 \mathrm{~mm}$ in summer ( $\mathrm{J}$ Matsapola, 5 May 2015). In the current study, matured South African unimproved indigenous goats (44) from the Agricultural Research Council and Tankwa goats (41) from Carnarvon Research Station were used. The goats at the Agricultural Research Council were kept on natural pasture and supplemented with hay grass during winter season and drinking water was provided ad libitum through metal drinking troughs.

The goats at Carnarvon Research Station on the other hand survived on natural veld with no supplementation during the winter season with access to drinking water. South African unimproved indigenous goats are commonly small sized animals, which stand harsh environments, parasites and diseases, have good maternal ability and are able to survive on poor quality grazing when compared to foreign breeds (Ramsay and Donkin, 2000). Tankwa goats were first discovered in the Tankwa Karoo National Park. It is believed that this goat type may have originated from indigenous goats that were in the area in the 1900s but have since been isolated (Kotze et al., 2014).

Phenotypic quantitative characteristics (body parts measurements) were assessed with the aid of a flexible tape measure and were recorded in centimetres $(\mathrm{cm})$. Individual body weight was determined by using a weighing scale and it was recorded in kilograms $(\mathrm{kg})$. The phenotypic qualitative characteristics were assessed through visual appraisal. Body condition score was assessed based on standard scale which ranges from 1 $5(1=$ very thin, $2=$ thin, $3=$ satisfactory, $4=$ fat and $5=$ obese) (Agga et al., 2011). The age of the males was estimated by counting the number of permanent incisors on the lower jaw of the mouth (Agga et al., 2011).

Phenotypic qualitative data were analysed using a Statistical software for Microsoft Excel (XLSTAT), Version 2013 (New York, USA). For categorical variables, descriptive statistics were determined and data was presented as simple proportions (percentages). Phenotypic quantitative characteristics data were 
analysed using the Generalised Linear Model procedures in the Statistical Analysis Software, Version 9.2 (SAS Institute Inc, 1999). LS-means were compared using the LSD test $(\alpha=0.05)$. The statistical model used was:

$$
y_{i j}=\mu+\tau_{i}+e_{i j}
$$

Where:

$y_{i j}=$ The observation of the $j$-th experimental unit of the $i$-th treatment

$\mu=$ The overall mean

$\tau_{i}=$ The effect of the i-th treatment or breed

$e_{i j}=$ The residual (error) component

\section{Results}

Table 1 depicted age, general and tail appearance characteristics of South African unimproved indigenous and Tankwa goats. None of the goats had a body condition score of 5 (very fat). South African unimproved indigenous goats did not have very thin (1) and thin (2) body condition scores. However, Tankwa goats had 2 and $18 \%$ of very thin (1) and thin (2) body condition scores, respectively. South African unimproved indigenous goats had a higher proportion of satisfactory (3) body condition score (98\%) when compared to Tankwa goats $(74 \%)$. None of the Tankwa goats had ticks under their tails compared to $53 \%$ for South African unimproved indigenous goats. Out of $47 \%$ South African unimproved indigenous goats that had ticks, $14 \%$ had 1 tick, another $14 \%$ had 2 ticks, $5 \%$ had 3 ticks, $12 \%$ had 4 ticks and $2 \%$ had 5 ticks.

Table 2 depicted coat cover characteristics of South African unimproved indigenous and Tankwa goats.
South African unimproved indigenous goats had $61 \%$ of long fibre, which was higher when compared to Tankwa goats $(25 \%)$. Tankwa goats had a higher proportion of coat cover with single $(21 \%)$ and two colours $(59 \%)$ when compared to South African unimproved indigenous goats (5\% single and $39 \%$ two colours). However, South African unimproved indigenous goats had a higher proportion of more than two coat colours $(56 \%)$ when compared to Tankwa goats $(20 \%)$. White $(56 \%)$ and brown colours $(35 \%)$ were more dominant in South African unimproved indigenous goats as the main coat colours, with black colour being the less dominant colour. In Tankwa goats, black colour (49\%) was more dominant, followed by brown (26\%), red (13\%), white $(10 \%)$ and grey $(2 \%)$ colour, which were higher when compared to South African unimproved indigenous goats' black, red and grey colour, 9, 0 and $0 \%$, respectively.

Table 3 depicted skin characteristics of South African unimproved indigenous and Tankwa goats. South African unimproved indigenous goats had a higher proportion of small and tight $(18 \%)$ and big and loose (56\%) skin when compared to Tankwa goats small and tight $(14 \%)$ and big and loose (16\%) skin. Moreover, South African unimproved indigenous goats had a higher proportion of thick skin (47\%) when compared to Tankwa goats $(33 \%)$. There was a higher proportion of black $(80 \%)$, brown (14\%) and red $(2 \%)$ colours in Tankwa goats when compared to South African unimproved indigenous goats' black, brown and red colours, 14, 3 and $0 \%$, respectively. Moreover, a higher proportion of skin part that were not covered with hair was observed in Tankwa goats $(100 \%)$ than in South African unimproved indigenous goats $(31 \%)$.

Table 1: Age, general and tail appearance characteristics of South African unimproved indigenous and Tankwa goats (\%)

\begin{tabular}{|c|c|c|c|c|}
\hline \multirow[b]{2}{*}{ Characteristics } & & \multirow[b]{2}{*}{ Categories } & \multicolumn{2}{|l|}{ Breeds } \\
\hline & & & Unimproved $(n=44)$ & Tankwa $(\mathrm{n}=41)$ \\
\hline \multirow[t]{5}{*}{ Age (years) } & Age based on number & 1 & 0 & 8 \\
\hline & of permanent incisors & 2 & 30 & 10 \\
\hline & & 3 & 58 & 27 \\
\hline & & 4 & 10 & 45 \\
\hline & & $>5$ & 2 & 10 \\
\hline \multirow[t]{5}{*}{ General appearance } & Body condition score & Very thin (1) & 0 & 2 \\
\hline & & Thin (2) & 0 & 18 \\
\hline & & Satisfactory (3) & 98 & 74 \\
\hline & & Fat (4) & 2 & 6 \\
\hline & & Very fat (5) & 0 & 0 \\
\hline \multirow[t]{8}{*}{ Tail } & Appearance & Straight & 100 & 73 \\
\hline & & Skew & 0 & 27 \\
\hline & & None & 53 & 100 \\
\hline & Ticks & 1 & 14 & 0 \\
\hline & & 2 & 14 & 0 \\
\hline & & 3 & 5 & 0 \\
\hline & & 4 & 12 & 0 \\
\hline & & 5 & 2 & 0 \\
\hline
\end{tabular}

The results are comparable within the same cell on the same row. 
Table 2: Coat cover characteristics of South African unimproved indigenous and Tankwa goats (\%)

\begin{tabular}{|c|c|c|c|c|}
\hline \multirow[b]{2}{*}{ Characteristi } & & \multirow[b]{2}{*}{ Categories } & \multicolumn{2}{|l|}{ Breeds } \\
\hline & & & Unimproved $(\mathrm{n}=44)$ & Tankwa $(\mathrm{n}=41)$ \\
\hline \multirow[t]{17}{*}{ Coat cover } & \multirow[t]{3}{*}{ Appearance } & Coarse & 35 & 14 \\
\hline & & Average & 63 & 31 \\
\hline & & Glossy and shine & 2 & 55 \\
\hline & \multirow[t]{3}{*}{ Fibre form } & Straight & 100 & 71 \\
\hline & & Curly & 0 & 25 \\
\hline & & Both & 0 & 4 \\
\hline & \multirow[t]{3}{*}{ Length } & Short & 0 & 22 \\
\hline & & Medium & 39 & 53 \\
\hline & & Long & 61 & 25 \\
\hline & \multirow[t]{3}{*}{ Colour } & Single & 5 & 21 \\
\hline & & Two & 39 & 59 \\
\hline & & More & 56 & 20 \\
\hline & \multirow[t]{5}{*}{ Main colour } & Brown & 35 & 26 \\
\hline & & Black & 9 & 49 \\
\hline & & Red & 0 & 13 \\
\hline & & White & 56 & 10 \\
\hline & & Grey & 0 & 2 \\
\hline
\end{tabular}

The results are comparable within the same cell on the same row.

Table 3: Skin characteristics of South African unimproved indigenous and Tankwa goats (\%)

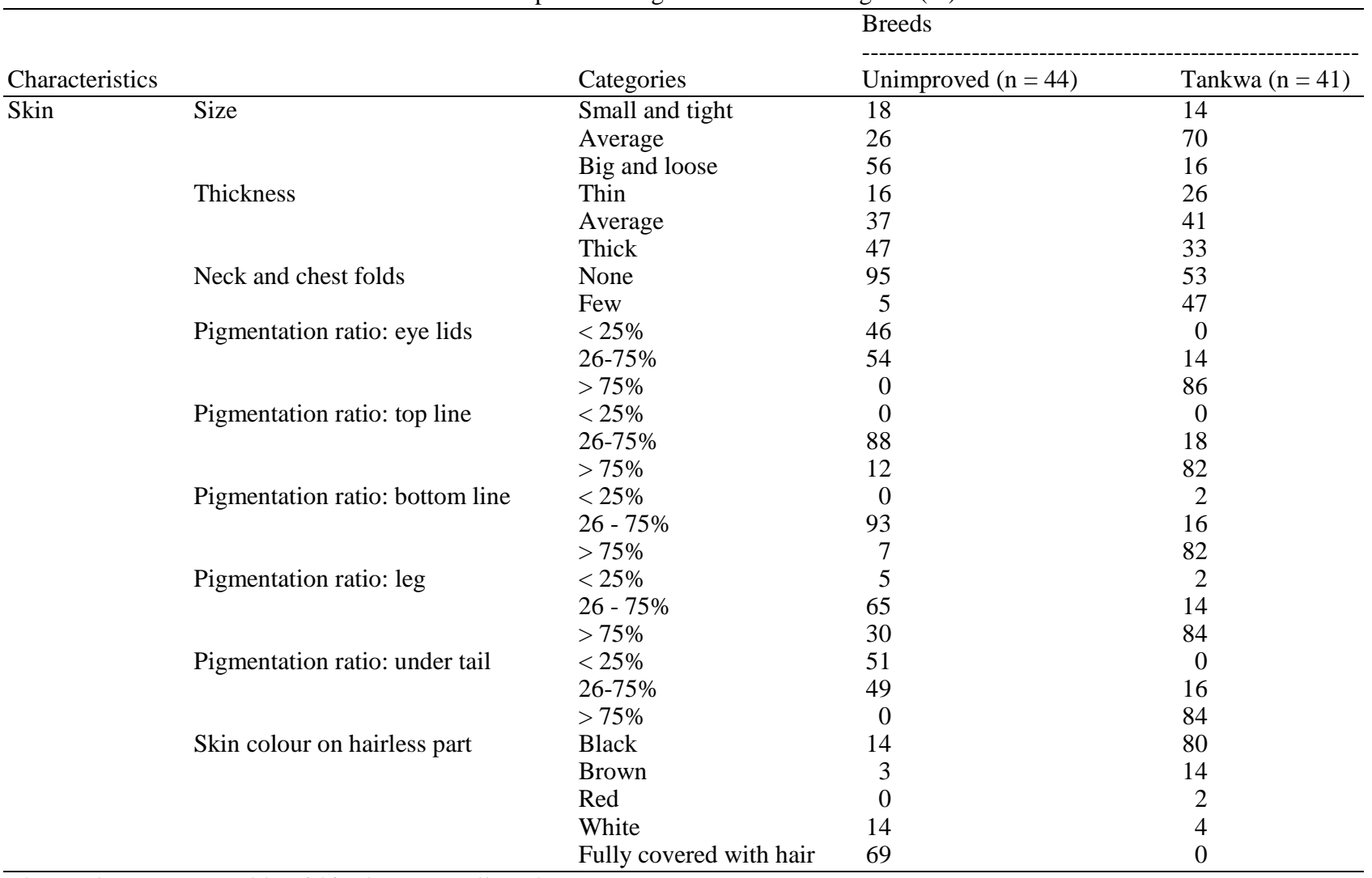

The results are comparable within the same cell on the same row.

Table 4 depicted head characteristics of South African unimproved indigenous and Tankwa goats. Both South African unimproved indigenous and Tankwa goats had brown eyes and did not have blue eyes. South African unimproved indigenous goats had a higher proportion of individuals without eye banks $(74 \%)$ when compared to
Tankwa goats (8\%). A higher proportion of untamed males were observed in Tankwa goats (88\%) when compared to South African unimproved indigenous goats $(2 \%)$. The mouth shapes of Tankwa goats were average (100\%) which was higher when compared to South African unimproved indigenous goats $(91 \%)$. On the other hand, Tankwa goats 
had a higher proportion of males with undershot (14\%) and overshot (2\%) lower jaws when compared to South African unimproved indigenous goats undershot (5\%) and overshot $(0 \%)$ lower jaws. South African unimproved indigenous goats had a higher proportion of males with beards $(100 \%)$ when compared to Tankwa goats $(92 \%)$. Tankwa goats had a higher proportion of males that had toggles (10\%) when compared to South African unimproved indigenous goats $(0 \%)$.

Table 5 depicted horn and ear characteristics of South African unimproved indigenous and Tankwa goats. All South African unimproved indigenous and Tankwa goats had horns. Tankwa goats had a higher proportion of horns that were dark in colour $(33 \%)$ when compared to South African unimproved indigenous goats (23\%). There was a higher proportion of horns that were undamaged in South African unimproved indigenous goats (98\%) when compared to Tankwa goats (47\%). Tankwa goats had a higher proportion of long ears (51\%) when compared to South African unimproved indigenous goats (9\%). Tankwa goats had a higher proportion of soft hanging ears $(96 \%)$ when compared to South African unimproved indigenous goats (47\%).

Table 6 depicted neck, chest, shoulder and torso characteristics of South African unimproved indigenous and Tankwa goats. Both South African unimproved indigenous and Tankwa goats had the same proportion of well-fleshed necks (21\%). Tankwa goats had a higher proportion of shoulders that were ideally attached to the body (63\%) when compared to South African unimproved indigenous goats (19\%). On the other hand, South African unimproved indigenous goats showed a higher proportion of cylindrical torsos $(77 \%)$ when compared to Tankwa goats (31\%). Table 7 depicted hind quarter characteristics of South African unimproved indigenous and Tankwa goats. Tankwa goats had a higher proportion of sloped $(80 \%)$, average $(14 \%)$ and straight $(6 \%)$ rumps when compared to South African unimproved indigenous goats sloped $(77 \%)$, average $(0 \%)$ and straight $(0 \%)$ rumps. South African unimproved indigenous goats had $23 \%$ of roofy rumps, whereas Tankwa goats did not have any roofy rumps.

Table 8 depicted legs characteristics of South African unimproved indigenous and Tankwa goats. Tankwa goats had a higher proportion of thin $(8 \%)$ and thick (4\%) leg diameters when compared to South African unimproved indigenous goats leg diameters $(5 \%$ thin and $0 \%$ thick). South African unimproved indigenous goats had a higher proportion of front legs that were normal $(98 \%)$ when compared to Tankwa goats $(69 \%)$.

Table 4: Head characteristics of South African unimproved indigenous and Tankwa goats (\%)

\begin{tabular}{|c|c|c|c|c|}
\hline \multirow[b]{2}{*}{ Characteristics } & & \multirow[b]{2}{*}{ Categories } & \multicolumn{2}{|l|}{ Breeds } \\
\hline & & & Unimproved $(n=44)$ & Tankwa $(\mathrm{n}=41)$ \\
\hline \multirow{6}{*}{ Head } & Nose and forehead shape & Convex & 16 & 67 \\
\hline & & Straight & 65 & 31 \\
\hline & & Concave & 19 & 2 \\
\hline & \multirow[t]{2}{*}{ Eye colour } & Brown & 100 & 100 \\
\hline & & Blue & 0 & 0 \\
\hline & \multirow[t]{3}{*}{ Eye width } & Narrow & 2 & 2 \\
\hline & & Average & 94 & 94 \\
\hline & & Wide & 4 & 4 \\
\hline & \multirow[t]{3}{*}{ Eye banks } & Absent & 74 & 8 \\
\hline & & Average & 26 & 74 \\
\hline & & Distinct/separate & 0 & 18 \\
\hline & \multirow[t]{2}{*}{ Look in the eye } & Untamed & 2 & 88 \\
\hline & & Tamed & 98 & 12 \\
\hline & \multirow[t]{2}{*}{ Nostrils } & Small and closed & 70 & 14 \\
\hline & & Wide and open & 30 & 86 \\
\hline & \multirow[t]{3}{*}{ Shape of mouth } & Narrow & 7 & 0 \\
\hline & & Average & 91 & 100 \\
\hline & & Wide & 2 & 0 \\
\hline & \multirow[t]{3}{*}{ Lower jaw } & Undershot & 5 & 14 \\
\hline & & Fits well & 95 & 84 \\
\hline & & Overshot & 0 & 2 \\
\hline & \multirow[t]{2}{*}{ Beards } & Absent & 0 & 8 \\
\hline & & Present & 100 & 92 \\
\hline & \multirow[t]{2}{*}{ Toggles } & Absent & 100 & 90 \\
\hline & & Present & 0 & 10 \\
\hline
\end{tabular}

The results are comparable within the same cell on the same row. 
Fhulufhelo Vincent Ramukhithi et al. / American Journal of Animal and Veterinary Sciences 2019, 14 (4): 207.220 DOI: 10.3844/ajavsp.2019.207.220

Table 5: Horn and ear characteristics of South African unimproved indigenous and Tankwa goats (\%)

\begin{tabular}{|c|c|c|c|c|}
\hline \multirow{2}{*}{\multicolumn{2}{|c|}{ Characteristics }} & \multirow[b]{2}{*}{ Categories } & \multicolumn{2}{|l|}{ Breeds } \\
\hline & & & Unimproved $(n=44)$ & Tankwa $(\mathrm{n}=41)$ \\
\hline \multirow[t]{13}{*}{ Horns } & Type & Horned & 100 & 100 \\
\hline & & Polled & 0 & 0 \\
\hline & Growth direction & Backward & 67 & 92 \\
\hline & & Sideways & 3 & 8 \\
\hline & & Upright & 30 & 0 \\
\hline & Shape & Curved & 77 & 86 \\
\hline & & Straight & 9 & 14 \\
\hline & & Spiral & 14 & 0 \\
\hline & Colour & Dark & 23 & 33 \\
\hline & & Light & 77 & 67 \\
\hline & Deviation & Undamaged & 98 & 47 \\
\hline & & Damaged & 0 & 51 \\
\hline & & Right horn damaged & 2 & 2 \\
\hline \multirow[t]{7}{*}{ Ears } & Size & Short & 7 & 4 \\
\hline & & Average & 84 & 45 \\
\hline & & Long & 9 & 51 \\
\hline & Direction & Soft hanging & 47 & 96 \\
\hline & & Stiff side ways & 53 & 4 \\
\hline & Folds & Length wise & 79 & 82 \\
\hline & & Breadth wise & 21 & 16 \\
\hline
\end{tabular}

The results are comparable within the same cell on the same row.

Table 6: Neck, chest, shoulder and torso characteristics of South African unimproved indigenous and Tankwa goats (\%)

\begin{tabular}{|c|c|c|c|c|}
\hline \multirow[b]{2}{*}{ Characteristics } & & \multirow[b]{2}{*}{ Categories } & \multicolumn{2}{|l|}{ Breeds } \\
\hline & & & Unimproved $(n=44)$ & Tankwa $(\mathrm{n}=41)$ \\
\hline \multirow[t]{6}{*}{ Neck } & Length & Short & 2 & 20 \\
\hline & & Moderate & 93 & 72 \\
\hline & & Long & 5 & 8 \\
\hline & Shape & Thin & 2 & 10 \\
\hline & & Fleshed & 77 & 69 \\
\hline & & Well fleshed & 21 & 21 \\
\hline \multirow[t]{6}{*}{ Chest } & Width & Narrow & 16 & 47 \\
\hline & & Average & 47 & 47 \\
\hline & & Wide & 37 & 6 \\
\hline & Depth & Shallow & 16 & 53 \\
\hline & & Average & 44 & 37 \\
\hline & & Deep & 40 & 10 \\
\hline \multirow[t]{12}{*}{ Shoulder and torso } & Attachment to body & Loose & 5 & 0 \\
\hline & & Average & 76 & 37 \\
\hline & & Ideal & 19 & 63 \\
\hline & Withers at the top & Sharp & 30 & 29 \\
\hline & & Average & 65 & 57 \\
\hline & & Broad & 5 & 14 \\
\hline & Torso & Narrow & 5 & 20 \\
\hline & & Cylindrical & 77 & 31 \\
\hline & & Broad and Deep & 18 & 49 \\
\hline & Top line & Pinched & 12 & 4 \\
\hline & & Straight & 74 & 65 \\
\hline & & Hollow & 14 & 31 \\
\hline
\end{tabular}

The results are comparable within the same cell on the same row. 
Table 7: Hind quarter characteristics of South African unimproved indigenous and Tankwa goats (\%)

\begin{tabular}{|c|c|c|c|c|}
\hline \multirow[b]{2}{*}{ Characteristics } & & \multirow[b]{2}{*}{ Categories } & \multicolumn{2}{|l|}{ Breeds } \\
\hline & & & Unimproved $(n=44)$ & Tankwa $(\mathrm{n}=41)$ \\
\hline \multirow{13}{*}{ Hind quarters } & Rump & Sloped & 77 & 80 \\
\hline & & Average & 0 & 14 \\
\hline & & Straight & 0 & 6 \\
\hline & & Roofy & 23 & 0 \\
\hline & Length & Short & 9 & 14 \\
\hline & & Average & 86 & 72 \\
\hline & & Long & 5 & 14 \\
\hline & Width & Narrow & 5 & 23 \\
\hline & & Average & 90 & 63 \\
\hline & & Broad & 5 & 14 \\
\hline & Buttocks and thighs & Short and flat & 95 & 10 \\
\hline & & Long and flat & 5 & 74 \\
\hline & & Well fleshed and round & 0 & 16 \\
\hline
\end{tabular}

The results are comparable within the same cell on the same row.

Table 8: Legs characteristics of South African unimproved indigenous and Tankwa goats (\%)

\begin{tabular}{|c|c|c|c|c|}
\hline \multirow[b]{2}{*}{ Characteristics } & & \multirow[b]{2}{*}{ Categories } & \multicolumn{2}{|l|}{ Breeds } \\
\hline & & & Unimproved $(n=44)$ & Tankwa $(\mathrm{n}=41)$ \\
\hline \multirow[t]{24}{*}{ Legs } & Diameter & Thin & 5 & 8 \\
\hline & & Average & 95 & 88 \\
\hline & & Thick & 0 & 4 \\
\hline & Front & Normal & 98 & 69 \\
\hline & & $\mathrm{X}$ legged & 2 & 27 \\
\hline & & Bow legged & 0 & 4 \\
\hline & Pasterns & Short & 12 & 21 \\
\hline & & Average & 88 & 69 \\
\hline & & Long & 0 & 10 \\
\hline & Hocks & Ideal & 100 & 94 \\
\hline & & Post legged & 0 & 4 \\
\hline & & Cow hocked & 0 & 2 \\
\hline & Hooves size & Small & 0 & 12 \\
\hline & & Average & 93 & 86 \\
\hline & & Big & 7 & 2 \\
\hline & Hooves condition & Poor & 7 & 40 \\
\hline & & Average & 25 & 18 \\
\hline & & Good and shiny & 68 & 42 \\
\hline & Hooves length & Well worn & 0 & 69 \\
\hline & & Good & 98 & 31 \\
\hline & & Too long & 2 & 0 \\
\hline & Heel size & Small & 0 & 8 \\
\hline & & Average & 93 & 86 \\
\hline & & Big & 7 & 6 \\
\hline
\end{tabular}

The results are comparable within the same cell on the same row.

However, a higher proportion of X (27\%) and bow (4\%) legs were observed in Tankwa goats than in South African unimproved indigenous goats' $X(2 \%)$ and bow $(0 \%)$ legs. South African unimproved indigenous goats had a higher proportion of ideal hocks $(100 \%)$ with no proportion of post legged $(0 \%)$ and cow hocked $(0 \%)$ hocks when compared to Tankwa goats ideal, post legged and cow hocked hocks, $94 \%, 4 \%$ and $2 \%$, respectively. South African unimproved indigenous goats had a higher proportion of hooves condition that were good and shiny $(68 \%)$ when compared to Tankwa goats $(42 \%)$.
Table 9 depicted testis characteristics of South African unimproved indigenous and Tankwa goats. South African unimproved indigenous goats had a higher proportion of well-balanced/equal (82\%), normal size (95\%), good attached (77\%) and straight (93\%) testis when compared to Tankwa goats (well-balanced/equal, normal size, good attached and straight testis, 70, 59, 76 and $88 \%$, respectively). Tankwa goats had a higher proportion of males without ticks on the testis $(100 \%)$ when compared to South African unimproved indigenous goats $(98 \%)$. 
Table 9: Testis characteristics of South African unimproved indigenous and Tankwa goats (\%)

\begin{tabular}{|c|c|c|c|c|}
\hline \multirow[b]{2}{*}{ Characteristics } & & \multirow[b]{2}{*}{ Categories } & \multicolumn{2}{|l|}{ Breeds } \\
\hline & & & Unimproved $(\mathrm{n}=44)$ & Tankwa $(\mathrm{n}=41)$ \\
\hline \multirow[t]{19}{*}{ Testis } & General appearance & Unequal in size & 9 & 10 \\
\hline & & Slightly unequal & 9 & 20 \\
\hline & & Well balanced/equal & 82 & 70 \\
\hline & Size & Small & 0 & 25 \\
\hline & & Normal & 95 & 59 \\
\hline & & Large & 5 & 16 \\
\hline & Attachment & Poor & 2 & 2 \\
\hline & & Average & 21 & 22 \\
\hline & & Good & 77 & 76 \\
\hline & Twist & $<45^{\circ}$ & 7 & 10 \\
\hline & & Straight & 93 & 88 \\
\hline & & $>45^{\circ}$ & 0 & 2 \\
\hline & Hair & Few & 2 & 20 \\
\hline & & Almost covered & 98 & 80 \\
\hline & Ticks & None & 98 & 100 \\
\hline & & 1 & 0 & 0 \\
\hline & & 2 & 0 & 0 \\
\hline & & 3 & 0 & 0 \\
\hline & & 4 & 0 & 0 \\
\hline
\end{tabular}

The results are comparable within the same cell on the same row.

Table 10: South African unimproved indigenous and Tankwa goats' phenotypic quantitative characteristics (LS-mean \pm SE)

\begin{tabular}{|c|c|c|c|c|}
\hline \multirow[b]{2}{*}{ Characteristics } & & & \multicolumn{2}{|l|}{ Breed } \\
\hline & & & Unimproved $(n=44)$ & Tankwa $(\mathrm{n}=41)$ \\
\hline \multirow[t]{2}{*}{ Body } & & Temperature $\left({ }^{\circ} \mathrm{C}\right)$ & $40.3^{\mathrm{a}} \pm 0.1$ & $38.5^{\mathrm{b}} \pm 0.1$ \\
\hline & & Weight $(\mathrm{kg})$ & $35.5^{\mathrm{b}} \pm 2.1$ & $59.8^{\mathrm{a}} \pm 1.9$ \\
\hline \multirow[t]{15}{*}{ Body parts $(\mathrm{cm})$} & Horns length & Left & $25.5^{\mathrm{b}} \pm 1.6$ & $35.2^{\mathrm{a}} \pm 1.5$ \\
\hline & & Right & $25.6^{\mathrm{b}} \pm 1.7$ & $36.4^{\mathrm{a}} \pm 1.5$ \\
\hline & Heart girth & Circumference & $80.9^{b} \pm 1.3$ & $95.5^{\mathrm{a}} \pm 1.2$ \\
\hline & Body & Length & $75.4^{\mathrm{b}} \pm 1.7$ & $111.8^{\mathrm{a}} \pm 1.6$ \\
\hline & & Height & $69.5^{\mathrm{b}} \pm 0.9$ & $79.1^{\mathrm{a} \pm} 0.9$ \\
\hline & & Depth & $23.9^{\mathrm{b}} \pm 0.6$ & $40.4^{\mathrm{a}} \pm 0.6$ \\
\hline & Rump & Width & $20.6^{\mathrm{b}} \pm 0.8$ & $45.2^{\mathrm{a}} \pm 0.7$ \\
\hline & Hind leg & Width & $16.6^{\mathrm{b}} \pm 0.4$ & $22.1^{\mathrm{a}} \pm 0.4$ \\
\hline & & Length & $45.9^{\mathrm{b}} \pm 0.9$ & $80.4^{\mathrm{b}} \pm 0.8$ \\
\hline & & Length below hock & $21.2^{\mathrm{a}} \pm 0.3$ & $24.5^{\mathrm{a}} \pm 0.3$ \\
\hline & & Length below knee & $19.2^{\mathrm{b}} \pm 0.3$ & $20.4^{\mathrm{a}} \pm 0.3$ \\
\hline & Hooves & Length & $6.7^{\mathrm{b}} \pm 0.1$ & $7.4^{\mathrm{a}} \pm 0.1$ \\
\hline & & Height & $4.1^{\mathrm{a}} \pm 0.1$ & $3.9^{\mathrm{b}} \pm 0.1$ \\
\hline & Testis & Circumference & $22.7^{\mathrm{b}} \pm 0.4$ & $27.3^{\mathrm{a}} \pm 0.4$ \\
\hline & Tail & Length & $13.3^{\mathrm{b}} \pm 0.3$ & $17.9^{\mathrm{a}} \pm 0.3$ \\
\hline
\end{tabular}

$\overline{\mathrm{a}, \mathrm{b}}$ Values with different superscripts within the same row differ significantly $(\mathrm{p}<0.05)$.

Table 10 depicted South African unimproved indigenous and Tankwa goats' phenotypic quantitative characteristics. South African unimproved indigenous goats had higher $(\mathrm{p}<0.05)$ body temperature $\left(40.3 \pm 0.1^{\circ} \mathrm{C}\right)$ when compared to Tankwa goats $\left(38.5 \pm 0.1^{\circ} \mathrm{C}\right)$. Tankwa goats were heavier $(\mathrm{p}<0.05)(59.8 \pm 1.9 \mathrm{~kg})$ when compared to South African unimproved indigenous goats $(35.5 \pm 2.1$ $\mathrm{kg})$. All the Tankwa goats body parts measured: length, height, depth; rump width, hind leg width, length, length below hock and knee, hooves height and length, tail length, heart girth and testicular circumference were longer $(p<0.05)$ when compared to South African unimproved indigenous goats.

\section{Discussion}

In the current study, both South African unimproved indigenous and Tankwa goats had satisfactory body 
condition score (3); with South African unimproved indigenous goats having a highest proportion (98\%) when compared to Tankwa goats $(74 \%)$. This might be because South African unimproved indigenous goats were supplemented with hay grass during the winter season (Nsoso et al., 2004) and the water was provided ad libitum. However, Tankwa goats did not receive any supplements and they were walking longer distances to get access to water. For South African unimproved indigenous goats, there were no males that had very thin and thin body condition score. However, Tankwa goats had $2 \%$ very thin and $18 \%$ thin body condition score. This might be due to unavailability of some nutrients (Nsoso et al., 2004), as the goats were on extensive farming system. According to Askar et al. (2015) nutrients supplementation enhances body condition score of an animal. If the nutrients are unbalanced, the consequences are weight loss, metabolic dysfunction and hormonal imbalance amongst others (Rosales-Nieto et al., 2011).

Although in Tankwa goats the body condition was generally poor compared to South African unimproved indigenous goats, the proportion of fattier goats was higher than in South African unimproved indigenous goats. This seems to be due to differences in management. Bucks with body condition score of 4 and above are culled at Agricultural Research Council because they were found to be less productive, lazy to mount and if they mount, they will mate few does (Penn State College of Agricultural Sciences, 2015; Pezzanite et al., 2015). However, at Carnarvon Research Station there was no culling for undesirable body condition. When the findings of the current study were compared with a previous study in Mexico, South African indigenous goats' body condition was much better when compared with Black Bedouin and Black Bedouin X Damascus goat males. The difference between the current and previous study might be due to different feeds that the goats had access to. In the current study, goats were exposed more to natural grazing, whereas, in Mellado et al. (2012) study the goats were fed with a commercial diet.

All the experimental goats used in this study were mature and optimal for breeding, as they were above 6 months of age (Pezzanite et al., 2015). In South African unimproved indigenous goats, the highest proportion was 3 years old, followed by 2 years old males and 4 years old males and the lowest proportion was 5 years old males and above. The reason why there was a low proportion of older males at the Agricultural Research Council is because of the culling process which is practiced (older goats are sold) (Nsoso et al., 2004). However, there was no culling of goats practiced at Carnarvon Research Station. The age of mature males at the Agricultural Research Council aligns well with Pezzanite et al. (2015), who indicated that the optimal breeding age of male goats ranges from 6 months to 4 years. Moreover, the age range of the goats at Agricultural Research Council seems to be a standard range that the intensive famers or research institutes are keeping (Kridli et al., 2007).

South African unimproved indigenous goats had few ticks under their tails and on the testis. This was indicated to have a good relationship with the skin thickness. It has been documented that, ticks bite more thick and loose skin than thin and tight skin (de Castro et al., 1991; Botha, 2007). In the current study, goats that had more tick bites had thicker and loose skin. This might be due to hair length as South African unimproved indigenous goats had long hair that might serve as ticks' carrier. Short hair was documented to develop much less static electricity when stroked and affords little protection against ticks, which do not like to be exposed to the sun. As a result, few ticks will attach themselves on the thick skin (Botha, 2007). In general, both South African unimproved indigenous and Tankwa goats were tolerant to ticks (Pieters, 2007).

Glossy and shiny hair was observed more in Tankwa goats than in South African unimproved indigenous goats. According to Akpa et al. (2013), hair type and coat pigment do not have an influence on body weight, conformation or semen parameters but indicate the productive adaptability of an animal. Glossy hair was reported to grow cashmere in cold winters (Snyman, 2014) and animals with glossy hair coat are less adaptable to hot climates, which makes them to be less productive when it is hot (Akpa et al., 2013). South African unimproved indigenous goats had straight fibre only. However, Tankwa goats had straight fibre (71\%), curly $(25 \%)$ and a combination of curly and straight fibre $(4 \%)$. These results are in agreement with Kayamadi (2007) who indicated that South African indigenous goats vary in coat type.

Hair type is an indication of an animals' physiological status, especially the functioning of the endocrine system and effectiveness of energy metabolism (Akpa et al., 2013). South African unimproved indigenous goats showed a high proportion of males that had long fibre when compared to Tankwa goats. The reason for this is not clear but it could be due to temperature variation in the two areas (Botha, 2007). Short hair was reported to have an advantage over long hair as it provides a medium for convectional heat loss from the animal surface and on the other hand, long hair serves as a carrier of external parasites (Botha, 2007; Akpa et al., 2013).

Most of the Tankwa goats had single or two colours as their main colours when compared to South African unimproved indigenous goats that had a high proportion of more than two colours. In Tankwa goats, black colour was more dominant followed by brown, red, white and 
grey, respectively. However, in South African unimproved indigenous goats, white colour was the most dominant colour followed by brown and black. Brown and white colours were more dominant in South African unimproved indigenous goats than in Tankwa goats. On the other hand, black, red and grey colours were dominant in Tankwa goats than in South African unimproved indigenous goats.

According to Hassen et al. (2012), coat colour has socio-cultural and economic values to African people. For example: black goats are less preferred in the Amhara region (Ethiopia) and Zululand region (South Africa) because they are believed to bring bad luck in the family. As a result, they have a direct effect on goat marketing value (Hassen et al., 2012; Phillips, 2013). The favourite colours in those regions were reported to be white, grey, brown and red (Phillips, 2013). In South Africa at Venda area, black goats are more preferred for rituals (Mashau, 2007) and are also believed to have good adaptation to cold weather as absorption of solar radiation by black pigment is faster than goats with other coat colours (Hassen et al., 2012; Okourwa, 2015).

The variation in colours observed in the current study was not surprising, as it has been documented that South African indigenous goats have a variety of colours (Kayamadi, 2007; Morrison, 2007; Snyman, 2014). This shows that South African indigenous goats in different areas of South Africa share some common characteristics. The colour domination and variation of these South African unimproved indigenous and Tankwa goats in the current study was suggested to be due to the genetic composition and breeding lines that are currently used and available at the Agricultural Research Council and Carnarvon Research Station. The multi and solid coloured patterns observed have been reported to help the goats to be difficult targets for predators, due to their different colorations (Morrison, 2007).

Most of the Tankwa goats had a convex forehead whereas South African unimproved indigenous goats had straight and concave foreheads. This is in agreement with Morrison (2007), who indicated that forehead shape tends to be flat or slightly concave in South African unimproved indigenous goats. Both South African unimproved indigenous and Tankwa goats had brown, narrow, average and wide eyes. Based on appearance of their eyes, South African unimproved indigenous goats were tamer than Tankwa goats. This might be due to the fact that South African unimproved indigenous goats are used to people during the trainings that are given to different stakeholders visiting the institute. Moreover, this might be due to handling (Kruger, 2014) when semen is collected, routine check of their well-being, counted and moved from one camp to the other etc. However, Tankwa goats are managed with little human interference. Taming of animals is beneficial for experimental purposes, as it changes animals' behaviour and physiology. However according to Mellor (2004), in a natural environment it is a disadvantage since it changes animals' responses to stimuli such as stock theft and predation.

All the South African unimproved indigenous goats had beards with no toggles. On the other hand, $92 \%$ of Tankwa goats had beards and $90 \%$ of them did not have toggles. In terms of the toggles, the results of current study are in line with the literature as it has been documented that toggles are dominantly found in dairy, pygmy and Spanish goats (Hassen et al., 2012). The presence of beards in both South African unimproved indigenous and Tankwa goats was expected, as it has been indicated that they are more dominant in males than in females, which flows into the longer hair of their neck (Snyman, 2014).

All the South African unimproved indigenous and Tankwa goats had horns and most of their horns were facing backwards. The presence of horns in animals is considered to be good for blood circulation through the cavernous sinus, as a control mechanism for thermal homeostasis (Food and Agriculture Organization, 2011; Hassen et al., 2012). It has also been anticipated that there is a good relationship between horns and male fertility in goats (Hassen et al., 2012). However, the current study did not confirm that. Horns serve as an excellent herding instinct that help animals to protect themselves from predators (Morrison, 2007). In the current study, different horns' shapes were observed. South African unimproved indigenous goats had upright, curved and spiral horns, whereas Tankwa goats had curved ones only. This is in agreement with the literature, as it has been documented that South African indigenous goats' horns shape vary (Kayamadi, 2007; Morrison, 2007) and are more inclined to curve backwards (Morrison, 2007).

Tankwa goats' horns were more damaged when compared to those of South African unimproved indigenous. This may be due to excessive use of their horns for self-defence against predators as they are not housed. It might also be due to environmental effects as Tankwa goats are currently staying at a rocky and mountainous environment. However, South African unimproved indigenous goats are staying in a plain and even environment without rocks and mountains (semiintensive) (Wiedemar et al., 2014). Tankwa goats' ears were longer when compared to South African unimproved indigenous goats that had short and average ears. According to Food and Agriculture Organization (2011), goats that have long ears are well adapted to dry and hot climatic conditions. This makes sense because the environmental temperatures at Carnarvon Research Station are higher when compared to the environmental temperatures at the Agricultural Research Council (J 
Matsapola, 5 May 2015). In terms of the ear type, Tankwa goats had more soft hanging ears with lengthwise folds when compared to South African unimproved indigenous goats. On the other hand, South African unimproved indigenous goats' had stiff and sideways facing ears with breadthwise folds. The results of the current study are in agreement with Kayamadi (2007) who indicated that South Africa indigenous goats' ears comes in different shapes and forms.

South African unimproved indigenous and Tankwa goats used in this study showed some close similarities with regards to withers, top lines, average chest width, necks, rump slope and length. Their fleshed necks might be due to the fact that their general body condition score was satisfactory. Tankwa goats' hooves condition were poor when compared to South African unimproved indigenous goats. However, this was not surprising as the environmental conditions where Tankwa goats were located was harsh when compared to the environmental conditions where the South African unimproved indigenous goats were kept. There was a high proportion of well-balanced testicles in South African unimproved indigenous and Tankwa goats. This means that their testicles were firm, movable within the scrotum and their sizes were good (Morrison, 2007; Pezzanite et al., 2015). However, Tankwa goats had a higher proportion of unequal, slight unequal, small, average and large testis when compared to South African unimproved indigenous goats. This was not surprising as at the Agricultural Research Council, breeding soundness evaluation is done on males, meaning that most of the males kept are superior or are good for breeding purposes (Akpa et al., 2013; Pezzanite et al., 2015).

South African unimproved indigenous goats' body temperature $\left(40.3^{\circ} \mathrm{C}\right)$ was higher when compared to Tankwa goats $\left(38.5^{\circ} \mathrm{C}\right)$. According to Robertshaw (2004), this is above the normal body temperature $\left(38.5-39.7^{\circ} \mathrm{C}\right)$ recommended for goats. This might be due to the fact that long hair makes heat loss from the animal surface a challenge (Akpa et al., 2013). The testicular circumference obtained in the current study was higher when compared to the testicular circumference of $17.3 \pm 0.26 \mathrm{~cm}$ recorded in Red Sokoto males (Akpa et al., 2013). Such difference might be due to breed and age differences (Gebre, 2007), as in Red Sokoto males, it ranged from 9-24 months (Akpa et al., 2013). However, in the current study the males' age ranged from 1 year to $>5$ years. The testicular circumference obtained in the current study was still within the acceptable range of 17 and $25 \mathrm{~cm}$ in young and older males, respectively, which is recommended to be used for breeding in goats (Kridli et al., 2005; Ajani et al., 2015).

All the Tankwa goats body parts measured: length, height, depth; rump width, hind leg width, length, length below hock and knee, hooves height and length, tail length, heart girth and testicular circumference were longer when compared to South African unimproved indigenous goats. In all the body parts measured, there was an increase as the goats' age increase. This is expected since animal size was reported to increase with age (Akpa et al., 2013). Tankwa goats were also heavier than the South African unimproved indigenous goats. This might be due breed and environment differences, variety of grass and shrub that they had access to at Carnarvon Research Station (nutrition) (Perez and Mateos, 1996; Gebre, 2007).

Generally, heart girth circumference, body weight, height, length and depth of the males in the current study were higher when compared to the findings of Keith et al. (2009); Pieters et al. (2009); Akpa et al. (2013). The differences might be due to age of the males, as in the current study males age ranged from 1 year to $>5$ years, whereas in the previous studies it ranged from 8 to 9 months (Keith et al., 2009), average of 12 months (Pieters et al., 2009) and 9 months to 2 years (Akpa et al., 2013). It might also be due to breed differences, as in the previous studies; Boer (Keith et al., 2009), Boer, Kalahari red, Savana (Pieters et al., 2009) and Red Sokoto goats (Akpa et al., 2013) were used. Both South African unimproved indigenous and Tankwa goats used in the current study were classified as large-sized animals as their body heights were above $>65 \mathrm{~cm}$ (Hassen et al., 2012). The body length and height obtained in the current study showed some similarities with Webb et al. (1998) who obtained a minimum body length and height of 56 and $51 \mathrm{~cm}$, respectively.

The average body height $(74.3 \pm 0.9 \mathrm{~cm})$, length $(93.6 \pm 1.7 \mathrm{~cm})$, rump width $(32.9 \pm 0.8 \mathrm{~cm})$ and heart girth circumference $(88.2 \pm 1.3 \mathrm{~cm})$ obtained in the current study were higher when compared to Ethiopian indigenous goats that are located on the same subtropical region: body height $(67.6 \pm 0.29 \mathrm{~cm})$, length $(63.2 \pm 0.29$ $\mathrm{cm})$, rump width $(13.6 \pm 0.08 \mathrm{~cm})$ and heart girth circumference $(72.4 \pm 0.32 \mathrm{~cm}$ ) (Hassen et al., 2012). Moreover, South African unimproved indigenous goats' body depth was higher when compared to other South African indigenous goats such as Boer, Kalahari and Savannah that had 26.4, 27.1 and $24.9 \mathrm{~cm}$, respectively (However, Tankwa goats' body depth was lower when compared to the other South African indigenous goats in the previous study (Pieter et al., 2009).

Body weights reported in the current study were higher when compared to Red Sokoto males' body weight $(15.02 \pm 0.46 \mathrm{~kg})$. The difference might be due to age differences, as in the current study males were older when compared to Red Sokoto males. The results in the current study align well with the literature as it has been documented that body weight is influenced by age, 
meaning that older goats are heavier than younger goats. The skeletal dimensions such as heart girth and body height are good indicators of body weight and condition score (Akpa et al., 2013). Both South African unimproved indigenous and Tankwa goats used in this study were lighter when compared to Black Bedouin and Black Bedouin X Damascus males (63.2 \pm 5.0 and $60.4 \pm 7.1 \mathrm{~kg}$, respectively) used in the previous study (Mellado et al., 2012). That might be due to breed differences and feeding regime as in Mellado et al. (2012) study a commercial diet was used to feed the experimental animals (Kridli et al., 2007), whereas in the current study they were grazing on natural pasture. However, some of the body measurements of South African unimproved indigenous and Tankwa goats' evaluated in the current study fall within the literature estimates from tropical and subtropical breeds (Nsoso et al., 2004).

South African unimproved indigenous and Tankwa goats' length below hock in the current study was lower when compared to other South African indigenous goats used in the previous study. This shows that there are breed differences on phenotypic characteristics. Moreover, South African unimproved indigenous goats' tail length was similar with other South African unimproved indigenous goats' tail length reported in the previous studies. However, Tankwa goats' tail length was shorter when compared to other South African indigenous goat tails length observed in a previous study (Pieters et al., 2009). Although in the current study it was not investigated, it was documented that body measurements are the indicators of potential reproductive performance (Hassen et al., 2012) such as growth status, development of sperm cells and semen production (Agga et al., 2011).

\section{Conclusion}

The qualitative characteristics were comparable between South African unimproved indigenous and Tankwa goats. However, quantitative characteristics of Tankwa goats were good, with the exception of body temperature. Most of the differences observed between Tankwa and South African unimproved indigenous goats seem to be due to genetics, environmental factors (i.e. rainfall and temperature) and management factors (i.e. health practices and feeding systems). This is the first study to report on the phenotypic characteristics in Tankwa goats. The information obtained in this study will contribute in decision-making policy for the conservation, breeding and improvement programmes of indigenous goats' genetic resources.

\section{Acknowledgement}

The technical support from the Agricultural Research Council, Tshwane University of Technology, National
Zoological Garden, National Research Foundation, Northern Cape Department of Agriculture, Land Reform and Rural Development; and University of the Western Cape is well appreciated.

\section{Funding Information}

The financial support from Department of Agriculture, Forestry and Fisheries and Council for Scientific and Industrial Research - Southern African Science Service Centre for Climate Change and Adaptive Land Management (TASK 229) is well appreciated.

\section{Author's Contributions}

Fhulufhelo Vincent Ramukhithi: Contributed on the original ideas of the manuscript, data collection, analysis and interpretation; and manuscript write up.

Khoboso Christina Lehloenya: Contributed on the original ideas of the manuscript and manuscript preparation.

Antoinette Kotze: Contributed on the original ideas of the manuscript, data collection and manuscript preparation.

Khathutshelo Agree Nephawe: Contributed on the original ideas of the manuscript and manuscript preparation.

Tshimangadzo Lucky Nedambale: Contributed on the original ideas of the manuscript and manuscript preparation.

Mokgadi Magdelin Seshoka: Contributed to data collection and interpretation.

Thinus Jonker: Contributed on the original ideas of the manuscript and data collection.

Tlou Caswell Chokoe: Gave valuable scientific inputs and data collection.

\section{Ethics}

This article is original and contains unpublished material. The corresponding author confirms that all of the other authors have read and approved the manuscript and no ethical issues involved.

\section{References}

African Union Interafrican Bureau for Animal Resources, 2014. Improving the utilization of Animal Genetic Resources characterization. S.I.: AU-ibar.org.

Agga, G.E., U. Udala, F. Regassa and A. Wudie, 2011. Body measurements of bucks of three goat breeds in Ethiopia and their correlation to breed, age and testicular measurements. Small Rumin. Res., 95: 133-138. DOI: 10.1016/j.smallrumres.2010.09.011 
Ajani, O.S., M.O. Oyeyemi and O.J. Moyinoluwa, 2015. Correlation between age, weight, scrotal circumference and the testicular and epididymal parameters of Red Sokoto bucks. J. Vet. Med. Anim. Health, 7: 159-163.

DOI: $10.5897 /$ JVMAH2014.0303

Akpa, G.N., A.L. Ambali and I.O. Suleiman, 2013. Body conformation, testicular and semen characteristics as influenced by age, hair type and body condition of Red Sokoto goat. N. Y. Sci. J., 6: 44-58.

Askar, A.R., T.A. Gipson, R. Puchala, K. Tesfai and G.D. Detweiler et al., 2015. Effects of supplementation and body condition on intake, digestion, performance and behavior of yearling Boer and Spanish goat wethers grazing grass/forb pastures. Small Rumin. Res., 125: 43-55. DOI: 10.1016/j.smallrumres.2015.02.011

Botha, T.C., 2007. Effect of selected physical and production traits on the tick burdens of beef cattle. M. Tech. Dissertation, Port Elizabeth, Nelson Mandela Metropolitan University, South Africa.

de Castro, J.J., P.B. Capstick, S. Nokoe, H. Kiara and F. Rinkanya et al., 1991. Towards the selection of cattle for tick resistance in Africa. Exp. Appl. Acarol., 12: 219-227. DOI: 10.1007/BF01193468

Esquivelzeta, C., M. Fina, R. Bach, C. Madruga and G. Caja et al., 2011. Morphological analysis and subpopulation characterization of Ripollesa sheep breed. Anim. Genet. Res., 49: 9-17.

DOI: $10.1017 / \mathrm{S} 2078633611000063$

Food and Agriculture Organization, 2007. Global plan of action for animal genetic resources and the interlaken declaration. Proceedings of the International Technical Conference on Animal Genetic Resources for Food and Agriculture, Sept. 3-7, Interlaken, Switzerland.

Food and Agriculture Organization, 2011. Commission on genetic resources for food and agriculture. Proceedings of the 13th Regular Session Draft Guidelines on Phenotypic Characterisation of Animal Genetic Resources, Jul. 18-22, Rome.

Food and Agriculture Organization, 2013. In-vivo conservation of animal genetic resources. FAO animal production and health guidelines, Rome.

Gebre, Y.M., 2007. Reproductive traits in Ethiopian male goats, with special reference to breed and nutrition. Doctoral Thesis, Acta Swedish University of Agricultural Sciences, Uppsala, Sweden.

Hassen, H., M. Baum, B. Rischkowsky and M. Tibbo, 2012. Phenotypic characterization of Ethiopian indigenous goat populations. Afr. J. Biotechnol., 11: 13838-13846. DOI: 10.5897/AJB12.2092

Kayamadi, 2007. Goat meat production, feasibility. Lepelle-Nkumpi local municipality. Limpopo Province, South Africa.
Keith, L., C. Okere, S. Solaiman and O. Tiller, 2009. Accuracy of predicting body weights from body conformation and testicular morphometry in pubertal Boer goats. Res. J. Anim. Sci., 3: 26-31. DOI: rjnasci.2009.26.31

Kotze, A., J.P. Grobler, E. van Marle-Koster, T. Jonker and D.L. Dalton, 2014. The Tankwa Karoo National Park feral goat population: A unique genetic resource. S. Afr. J. Anim. Sci, 44: 43-48. DOI: $10.4314 /$ sajas.v44i1.6

Kridli, R.T., M.J. Tabbaa and F.S. Barakeh, 2007. Seasonal variation in scrotal circumference and semen characteristics of Black Bedouin and Black Bedouin-Damascus crossbred bucks. AsianAustralas J. Anim. Sci., 20: 359-364. DOI: org/10.5713/ajas.2007

Kridli, R.T., M.J. Tabbaa, R.M. Sawalha and M.G. Amashe, 2005. Comparative study of scrotal circumference and semen characteristics of mountain black goat and its crossbred with Damascus goat as affected by different factors. Jordan J. Agric. Sci., 1: 18-24.

Kruger, L.P., 2014. The effect of environmental factors and husbandry practices on stress in goats. MSc. Dissertation, University of Pretoria, Pretoria.

Kunene, N., E.A. Nesamvuni and A. Fossey, 2007. Characterisation of Zulu (Nguni) sheep using linear body measurements and some environmental factors affecting these measurements. S. Afr. J. Anim. Sci., 37: 11-20. DOI: 10.4314/sajas.v37i1.4020

Manzi, M., T. Rutagwenda, N. Kanuya and P. Chatikobo, 2011. Phenotypic characterization of goats raised under traditional husbandry systems in Bugesera and Nyagatare districts of Rwanda. J. Anim. Vet. Adv., 10: 3297-3302. DOI: 10.3923/javaa.2011.3297.3302

Mara, L., S. Casu, A. Carta and M. Dattena, 2013. Cryobanking of farm animal gametes and embryos as a means of conserving livestock genetics. Anim. Reprod. Sci., 138: 25-38.

DOI: 1016/j.anireprosci.2013.02.006

Mashau, T.D., 2007. Occultism in an African context: a case for the Vhavenda-speaking people of the Limpopo Province. In die Skriflig, 41: 637-653. DOI: $10.4102 /$ ve.v37i1.1508

Mekasha, Y., 2007. Reproductive traits in Ethiopian male goats, with special reference to breed and nutrition. Doctoral Thesis, Swedish University of Agricultural Sciences, Sweden.

Mellado, M., C.A.M. Herrera, J.R. Arevalo, J.E. Garcia and F.G. Veliz, 2012. Effect of dietary energy intake and somatotropin administration after weaning on growth rate and semen characteristics of Granadina goat bucks. Turk. J. Vet. Anim. Sci., 36: 338-345. DOI: $10.3906 /$ vet-1101-721. 
Mellor, D.J., 2004. Taming and training of pregnant sheep and goats of newborn lambs, kids and calves before experimentation. Altern Lab Anim., 32: 143-146.

Microsoft Excel (XLSTAT), 2013. Version 2013. Addinsoft to Microsoft Excel 2013, New York, USA.

Morrison, J.W., 2007. A guide to the identification of the natural indigenous goats of Southern Africa.

Nsoso, S.J., B. Podisi, E. Otsogile, B.S. Mokhutshwane and B. Ahmadu, 2004. Phenotypic characterization of indigenous Tswana goats and sheep breeds in Botswana: continuous traits. Trop. Anim. Health. Prod, 36: 789-800.

DOI: 10.1023/B:TROP.0000045979.52357.61

Okourwa, M.I., 2015. Effect of coat characteristics on physiological traits and heat tolerance of West African Dwarf sheep in Southern Nigeria. Open J. Anim. Sci., 5: 351-357.

DOI: 10.4236/ojas.2015.54039

Penn State College of Agricultural Sciences, 2015. Breeding soundness.

Perez, B. and E. Mateos, 1996. Effect of photoperiod on semen production and quality in bucks of Verata and Malaguenia breeds. Small Rumin. Res., 22: 163-168. DOI: $10.1016 / \mathrm{S} 0921-4488(96) 00899-1$

Pezzanite, L., A. Bridges, M. Neary and T. Hutchens, 2015. Breeding soundness examinations of rams and bucks.

Phillips, 1., 2013. Communal goat farmer think commercial. Farmers Weekly.

Pieters, A., 2007. Genetic characterization of commercial goat populations in South Africa. Msc Dissertation, University of Pretoria, Pretoria.

Pieters, A., E. van Marle-Koster, C. Visser and A. Kotze, 2009. South African developed meat type goats: A forgotten animal genetic resource? Anim. Genetic Resource Inform., 44: 33-43. DOI: $10.1017 /$ S1014233900002844

Ramsay, K.A. and E.F. Donkin, 2000. A review of the current status of goat research and development in South Africa. Proceedings of the Regional Workshop on Goat Development in Southern Africa, Jul. 31-Aug. 4, Malawi, Mangochi.

Robertshaw, D., 2004. Temperature Regulation and the Thermal Environment. In: Dukes' Physiology of Domestic Animals, Reese, W.O. (Ed.), Cornell University Press, Ithaca, ISBN-13: 978-0801442384.

Roosen, J., A. Fadlaoui and M. Bertaglia, 2005. Economic evaluation for conservation of farm animal genetic resources. J. Anim. Breed. Genet., 122: 217-228.

DOI: 10.1111/j.1439-0388.2005.00530.x

Rosales-Nieto, C.A., H.G. Gamez-Vazquez, J. GudinoReyes, E.A. Reyes-Ramirez and M. Eaton et al., 2011. Nutritional and metabolic modulation of the male effect on the resumption of ovulatory activity in goats. Anim. Prod. Sci., 51: 115-122.

DOI: $10.1071 /$ AN10124
Sahlu, T., L.J. Dawson, T.A. Gipson, S.P. Hart and R.C. Merkel et al., 2009. ASAS Centennial Paper: Impact of animal science research on United States goat production and predictions for the future. J. Anim. Sci., 87: 400-418. DOI: 0.2527/jas.2008-1291

SAS Institute Inc, 1999. SAS/STAT User's Guide, Version 9, vol. 2 SAS Institute Inc, SAS Campus Drive, Cary, North Carolina 27513.

Snyman, M.A., 2014. South African Goat Breeds: Indigenous veld goat. Info-pack ref. 2014/004. Grootfontein Agricultural Development Institute.

Vallecillo, A., P.I. Trigo, J.V. Delgado, A. Cabello and E. Santos et al., 2004. Effects of cryopreservation on sperm motility in Blanca Serrana Andaluza Goat. S. Afr. J. Anim. Sci., 34: 116-118.

Visser, C., C.A. Hefer, E. van Marle-Koster and A. Kotze, 2004. Genetic variation of three commercial and three indigenous goat populations in South Africa. S. Afr. J. Anim. Sci., 34: 24-27. EID: 2-s2.021344453528

Webb, E.C., P.B. Cronje and E.F. Donkin, 1998. Research and training strategies for goat production systems in South Africa. Proceedings of the Goat Production in South Africa: Proceedings of the Constraints and Opportunities Workshop, Nov. 22-26, Eastern Cape, South Africa.

Wiedemar, N., J. Tetens, V. Jagannathan, A. Menoud and S. Neuenschwander et al., 2014. Independent polled mutations leading to complex gene expression differences in cattle. PLoS ONE, 9: 1-11. DOI: 0.1371/journal.pone.0093435

Yakubu, A., A.O. Raji and J.N. Omeje, 2010. Genetic and phenotypic differentiation of qualitative traits in Nigerian indigenous goat and sheep populations. Asian Res. Publish. Netw., 5: 58-66. DOI: 10.1.1.610.3565

Yami, A. and R.C. Merkel, 2008. Sheep and goat production handbook for Ethiopia: Ethiopia Sheep and Goat Productivity Improvement Program (ESGPIP) Ed. Branna Printing Enterprise, Ethiopia, pp: 38-62. 